\title{
経皮的レーザー椎間板減圧術（PLDD）後の手術例の検討
}

\author{
中部徳洲会病院整形外科 \\ 三 好 晋 爾·喜 瀬 均 \\ 北城 武司 \\ 琉球大学医学部整形外科 \\ 屋 良 哲 也・新 垣 勝 男 \\ 金 谷 文 則
}

\section{Salvaged Operation After Percutaneous Laser Disc Decompression}

\author{
Shinji Miyoshi, Hitoshi Kise, and Takeshi Kitashiro \\ Department of Orthopedic Surgery, \\ Chubu Tokushukai Hospital, Okinawa, Japan \\ Tetsuya Yara, Katsuo Arakaki, and Fuminori Kanaya \\ Department of Orthopedic Surgery, \\ School of Medicine, University of the Ryukyus
}

\begin{abstract}
Between 1996 and 1999, eleven males underwent salvaged operation after Percutaneous Laser Disc Decompression (PLDD) at other hospitals. Their age ranged from 28 to 92 years old (mean: 56.6 years) and follow-up period from 1 month to 37 months (mean: 19 months). PLDD was performed on the cervical spine in 4 cases and lumbar spine in 7 cases. The numbar of PLDDs ranged from 1 to 8 times (mean: 3.3). At the time of salvaged operation, our diagnosis was lumbar herniated intervertebral disc (LHID) in 4 cases, cervical pyogenic discitis (CPD) in 2, and indivisual cases of cervical spondylotic myelopathy (CSM), cervical ossification of the posterior longitudinal ligament (OPLL), lumbar canal stenosis (LCS), lumbar discopathy, and lumbar extradural abscess (LEA).

Salvaged operations were posterior discectomy in 4 cases of LHID, anterior decompression and fusion in 2 cases of CPD and OPLL, laminoplasty for CSM, PILF for LCS, PL-F for lumbar discopathy and laminectomy and debridement for LEA in one each.

The snspected causes for requiring salvaged operations were no improvement after PLDD with appropriate indication in 4 patients, no improvement with inappropriate indication in 3 , infection in 3 , and in one case the cause was unknown.
\end{abstract}

Key words : percutaneous laser disc decompression（経皮的レーザー椎間板減圧術）, salvaged operation（追加手術), complication（合併症）

\section{は じめに}

レーザーによって椎間板組織を蒸散する PLDD

(Percutaneous Laser Disc Decompression) は, 低侵襲性と後療法期間の短縮を利点として椎間板へル ニアに対する治療法の一つとして定着しつつある。一
般的な適応としては contained ヘルニア゚であり， 保存療法に抵抗をしめす症例があげられ，非適応とし ては骨性因子を含む症例や，椎間不安定性などが挙げ られる。しかし，安易にPLDDを施行され問題とな る例も少なくない．今回私たちはPLDD を他院で施 行され，当院にて追加手術を行った症例について検討 
したので報告する.

\section{対象及び方法}

他院で PLDD を施行され平成 8 年〜平成 11 年ま でに当院で手術を行った 11 人を対象とした。性別は 全例男性であり，年齢は 28９2 歳（平均 56.6 歳）て あった。他院での PLDD 前の診断が確認できたもの は, 頝椎椎間板ヘルニア1例のみであった，PLDD 前 の症状は脊䯣症状 3 例, 馬尾症状 1 例, 神経根症状 6 例, 腰痛のみが 1 例であった. PLDD の部位は腰椎 6 例, 頚椎 3 例, 䅡椎十腰椎 2 例であり回数は $1 \sim 8$ 回（平均 3.3 回）であった. 当院受診時の診断は腰椎 椎間板ヘルニアが 4 例, 頝椎化膿性椎間板炎が 2 例, 後緥靶带骨化症, 䅡椎症性脊髄症, 腰部脊柱管狭窄症, 腰椎椎間板症，腰椎硬膜外膿瘍が各 1 例であった。こ れらの症例を PLDD が無効であった症状遺残群と PLDD 後に症状が悪化したPLDD 後悪化群とに分 類し, 臨床症状, PLDD 適応の有無, 術式, 転帰に ついて検討した。

\section{結}

\section{果}

1. 症状遺残群 8 例（表 1)

PLDD が無効であった症状遺残群の術前診断は,
腰椎椎間板ヘルニアが 4 例, 後縦鞀帯骨化症, 澒椎症 性脊髄症, 腰部脊柱管狭窄症, 腰椎椎間板症が各 1 例 であった．腰椎椎間板へルニアは全て下肢の症状であ り，MRI 上は contained ヘルニアであったため, PLDDの適応があったと考えられた．PLDDは2 8 回と複数回行われていた。手術は 3 例にLove 法を 行い, PLDDを 8 回施行された 1 例は椎間不安定性 があったため, posterior lumbar interbody fusion（PLIF）を行った。手術所見では,ヘルニアは 全例 subligamentous extrusion であり，椎間腔は 空洞化していた，術後の症状は 4 例全て改善した。頚 椎後縦勒带骨化症, 頚椎症性脊髄症, 腰部脊柱管狭窄 症の 3 例は骨性因子を含むため, PLDD の適応はな かったと考えられた．手術はそれぞれ前方除圧固定術， 椎弓形成術, PLIF を行い症状はそれぞれ改善した。

2. PLDD 後悪化群 3 例（表 2)

症状悪化群は頚椎化膿性椎間板炎 2 例, 腰椎硬膜外 膿瘍 1 例であり, いずれも PLDD 後の感染例であっ た. 椎間板炎の 2 例の症状はそれぞれ上肢麻瘏，四肢 麻痺であり，PLDD の適応があったかどうかは不明 であった，手術は前方除圧固定術を行い症状は改善し た．起炎菌は 2 例とも表皮ブドウ球菌であった．硬膜 外膿瘍の 1 例は, 症状は腰痛であり, PLDD の適応

表 1 症状遺残群 8 例

\begin{tabular}{|c|c|c|c|c|c|c|}
\hline 診断名 & 年 齢 & PLDD 回数 & 部 位 & 症 状 & 手 術 & 転 帰 \\
\hline 腰椎椎間板ヘルニア & 34 & 8 回 & 腰 椎 & 下肢痛 & PLIF & 改 善 \\
\hline " & 28 & 3 回 & " & " & LOVE & " \\
\hline " & 43 & 4 回 & " & 下肢しびれ & " & " \\
\hline " & 71 & 2 回 & " & " & " & \\
\hline 後縦靫帯骨化症 & 64 & 3 回 & 頝 椎 & 脊髄症 & ASF & " \\
\hline 頝椎症性脊䯣症 & 55 & 䅡 2 回+腰 3 回 & 頝腰椎 & " & LP & " \\
\hline 腰部脊柱管狭窄症 & 69 & 䅡 3 回+腰 3 回 & " & 下肢痛 & PLIF & " \\
\hline 腰椎椎間板症 & 33 & 2 回 & 腰 椎 & 腰 痛 & PL-F & " \\
\hline
\end{tabular}

表 2 PLDD 後悪化群 3 例

\begin{tabular}{|c|c|c|c|c|c|c|}
\hline 診断名 & 年 齢 & PLDD 回数 & 部 位 & 症 状 & 手 術 & 転 㷌 \\
\hline 澒椎化膿性椎間板炎 & 63 & 2 回 & 䅡 椎 & 上肢麻瘏 & ASF & 改 善 \\
\hline & 49 & 1 回 & " & 四肢麻痺 & " & " \\
\hline 腰椎硬膜外膿瘍 & 92 & 1 回 & 腰 椎 & 腰 痛 & LMY & 死亡** \\
\hline \multicolumn{7}{|c|}{$\begin{array}{c}\mathrm{ASF} \text { : 前方除圧固定術 } \\
\quad * \text { : 術後敗血症 }\end{array}$} \\
\hline
\end{tabular}


は不明であった．手術は椎弓切除術及びデブリードマ ンを行い，起炎菌はメチシリン耐性ブ菌であった，術 後敗血症により死亡した.

症例

症例 1:64 歳 男性（図 1)

平成 10 年 9 月頃より四肢のしびれが出現したため,
近医を受診し䅡椎に対し PLDDを 3 回施行された。 しかし，症状の改善が見られなかったため，平成 11 年 1 月 28 日当院を受診した。単純レ線像及び断層像 にて C5７に連続性 OPLL を認め, MRI では脊髄 の圧迫を認めた。春髄症を呈し来院時の JOA スコア は 9 点であった。同年 2 月 25 日前方除圧固定術を行 い, 術後 1 カ月の MRI で脊䯣の圧迫は軽減し， 1 年

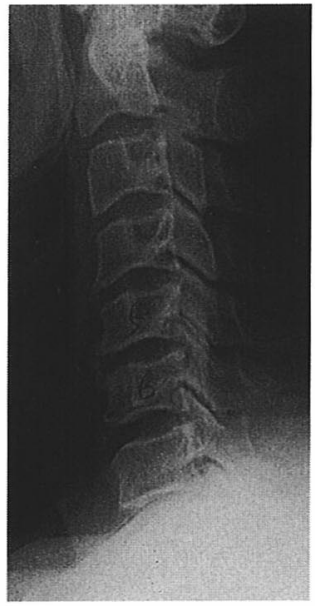

a

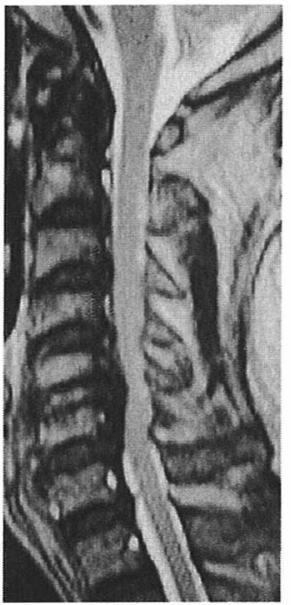

b

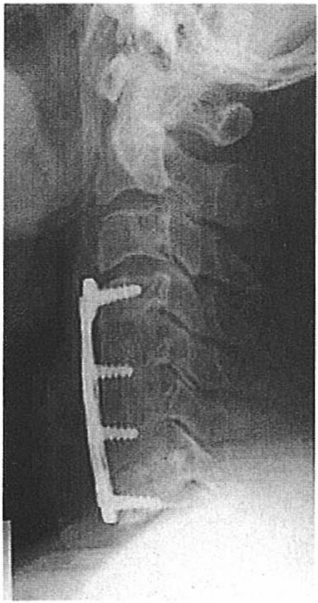

c

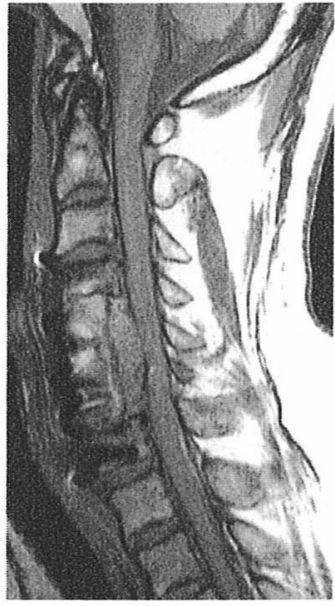

d

図 164 歳 男性 頚椎後縦靫带骨化症

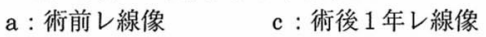

$\mathrm{b}$ : 術前 MRI $\mathrm{T}_{2} \mathrm{~d}:$ 術後 1 力月 $\mathrm{MRI} \mathrm{T}_{2}$

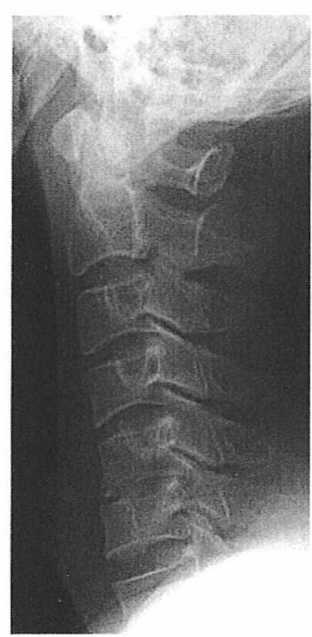

a

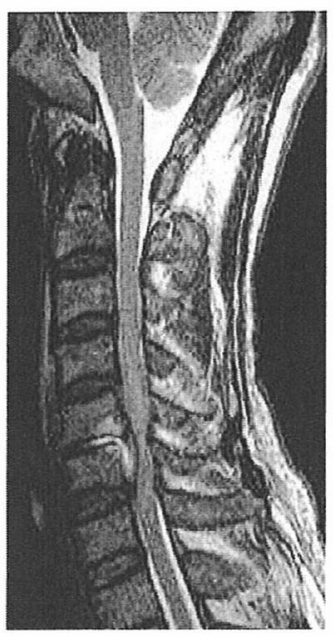

b

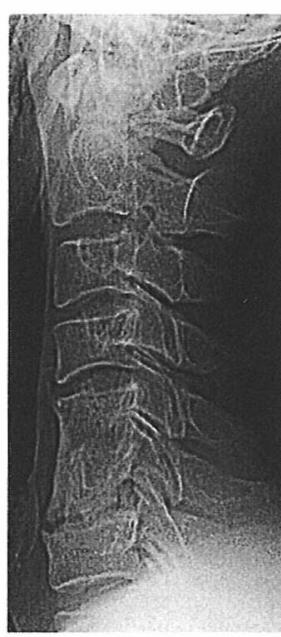

c

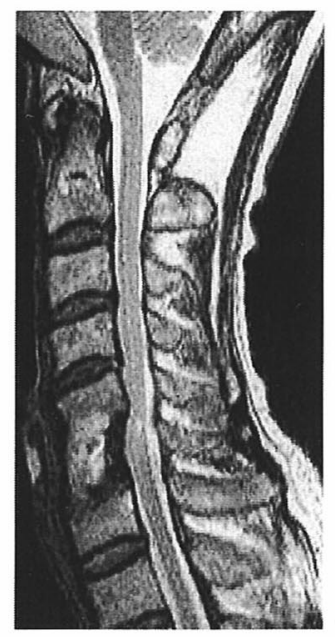

d

図 249 歳 男性 顓椎化膿性椎間板炎

$\mathrm{a}$ : 術前レ線像 $\quad \mathrm{c}$ : 術後 1 年レ線像

$\mathrm{b}:$ 術前 MRI $\mathrm{T}_{2} \mathrm{~d}:$ 術後 1 年 MRI $\mathrm{T}_{2}$ 
では骨癒合も得られ, JOA スコアは 15 点となり改善 率は $75 \%$ であった（図 1 )。

症例 $2: 49$ 歳 男性

97 年 11 月頃より頝部痛, 両上肢のしびれが出現し, 98 年 10 月より症状悪化し, 近医を受診した。MRI にて C5/6にヘルニアが認められたため, PLDDを 1 回施行された。 その数日後より, 発熱や四肢麻痷の悪 化のため，同年 11 月 30 日に当院を受診した。単純し 線像にて C $5 / 6$ 椎間狭小化を認め, MRI では椎間腔 から脊柱管に至る炎症性肉芽を認め，脊髄は著明に圧 迫されていた．来院時の JOA スコアは 0 点であり， 完全四肢麻瘦を呈していた。頚椎化膿性椎間板炎を疑 い，12月 1 日に前方除圧固定術を施行し，術中の培 養検査で表皮ブドウ球菌が検出された。術後 1 年のレ 線像で骨癒合は不十分であるが，MRIでは脊髄の圧 迫は認められず，JOA スコアは 15 点となり改善率は 88\%であった。

\section{考察}

PLDD の一般的な適応としては contained ヘルニ アであり，保存療法に抵抗をしめす症例があげられる. 非適応としては骨性因子を含む症例や，椎間不安定性 などが挙げられる。ヘルニアのタイプでは protrusion 及び subligamentous extrusionは適応があ $り$, transligamentous extrusion 及び sequestrationは非適応と考えられる。

PLDD 後に手術に至った原因は, 腰椎椎間板へル ニアの 4 例では骾核とへルニアに連続性を認め, 下肢 症状を有したことより PLDD の適応があったと考え られる。しか, Love 法抢よびPLIF を施行した 4 例 のヘルニアのタイプは全て subligamentous extrusionであり斯波ら ${ }^{3)}$ による subligamentous extrusionでは椎間板の変性や大きなへルニア例では PLDD の成績は安定しなかったと述べている。この 4 例はPLDD の無効例であった可能性があり，
PLDD を複数回行うより，手術を考慮すべきであっ たと考えられた。

後縦勒带骨化症, 颈椎症性脊髄症, 腰部脊柱管狭窄 症の 3 例は，骨性因子が関与しているため, PLDD の適応はなかったと考えられ，頚椎化膿性椎間板炎 2 例と腰椎硬膜外膿貆 1 例は PLDD 後の感染例であり, 手技上の問題と考えられた。腰椎椎間板症の 1 例は PLDD 後の終板障害であると考えられた.

PLDD の合併症としては, 感染, 終板障害, 神経 根穿刺, 椎間不安定性の出現などが挙げられる。 PLDD 後の感染は $\mathrm{Choy}^{1)}$ は $0.12 \%$ ，西島 ${ }^{2)}$ は 0.78\% と報告しており，必ずしも多くはない。一方， 鈴木 ${ }^{4)}$ らは PLDD 後悪化例 10 例中, 感染例は 4 例で あったと報告しており，私達の症例でも症状悪化群の 3 例全てに感染が認められた。このことから PLDD 後に症状が悪化したものは感染を念頭におくべきと考 えられた。

\section{ま と め}

(1)他院での経皮的レーザー椎間板減圧術後の手術例 を検討した。

(2)再手術の原因は椎間板ヘルニアの無効 4 例, 適応 外 3 例，感染合併 3 例，不明 1 例であった.

(3)手術により 10 例は症状は改善し， 1 例は術後敗 血症により死亡した。

\section{参 考 文 献}

1) Choy, D. et al.: Percutaneous Laser Disc Decompression. Spine, $17: 949-956,1992$.

2) 西島雄一郎, 石塚弘和 : レーザー腰椎椎間板除圧術。 新 OSNOW 最新の脊椎外科, pp.62-69, 阿部宗昭, 東京 都, 中尾俊治, 2000 .

3）斯波卓哉, 里見和彦, 河合 大 : 腰椎椎間板ヘルニア に対するレーザー椎間板減圧術。JMIOS，15：33-38, 2000.

4）鈴木省三, 山本利美雄 : 腰椎レーザー椎間板除圧術後 の終板障害とその対策. JMIOS, $15: 53-58,2000$. 